\title{
Essential oil composition of leaf and fine stem of Aniba canelilla (Kunth) Mez from Manaus, Brazil.
}

\author{
Maria da Paz LIMA ${ }^{1}$, Tatiana Maria D. SILVA ${ }^{1}$, João Domingos da SILVA ${ }^{1}$, Maria das Graças B. ZOGHBI ${ }^{2}$, Eloisa \\ Helena A. ANDRADE ${ }^{2}$
}

\begin{abstract}
The essential oil of the leaves and fine stems of Aniba canelilla (Kunth) Mez collected in the city of Manaus, AM, Brazil, were obtained by hydrodistillation and analyzed by GC/MS. Forty-two components were identified, of which 1-nitro-2phenylethane, as expected, was the major (71.2\%-68.2\%).

KEY WORDS

Aniba canelilla, Lauraceae, essential oil composition, 1-nitro-2-phenylethane.

\section{Os óleos essenciais das folbas e galbos finos de Aniba canelilla (Kuntb) Mez coletados em Manaus, Brasil.}

\section{RESUMO}

Os óleos essenciais das folhas e dos galhos finos de Aniba canelilla (Kunth) Mez coletada na cidade de Manaus, AM, Brasil, foram obtidos por hidrodestilação e analisados por CG-EM. Quarenta e dois componentes foram identificados, dos quais 1-nitro-2-feniletano, como esperado, foi o que apresentou maior porcentagem $(71,2 \%-68,2 \%)$.

\section{PALAVRAS-CHAVE}

Aniba canelilla, 1-nitro-2-feniletano, composição química de óleos essenciais.

Aniba canelilla (Kunth) Mez (Lauraceae) (syn: Aniba elliptica A. C. Sm., Cryptocarpa canelilla Kunth), locally known as "casca-preciosa", is a large tree endemic to South America. Bark infusions have been used to treat diarrhea, coughs, and as a antispasmodic and stimulant for the nervous system (Corrêa, 1984; Martins, 1989; Almeida, 1993). 1-Nitro-2-phenylethane and methyleugenol were the major compounds identified in the essential oil of A. canelilla (Gottlieb \& Magalhães, 1960; Morais et al., 1972; Oger et al., 1994; Taveira et al., 2003). The percentage content of these two compounds are reported as depending on soil and the seasonal period of collections in the Amazon that was higher in the rainy season (Taveira et al., 2003). The alkaloids of A. canelilla have been reported (Oger et al., 1993). The fungistatic activity of 1-nitro-2-phenyletahane and the $\mathrm{LD}_{50}$ of a petroleum ether extract from this plant was determined (Oger et al., 1994). This paper relates the chemical composition of the oil obtained from the leaves and fine stems of A. canelilla.

The samples of $A$. canelilla were collected on the Instituto Nacional de Pesquisas da Amazônia (INPA) campus, in Manaus, in the state of Amazonas, Brazil, in november 2001. A voucher especimen (\#210071) was kept in the Herbarium of INPA. The leaves (188g) and fine stems (80g), dried at room temperature for 7 days, were subjected to hydrodistillation for $4 \mathrm{~h}$, using a Clevenger-type apparatus to produce oil yields of $0.8 \%$ and $0.2 \%$, respectively. GC/MS analysis was performed on a Finnigan Mat INCOS XL GC/MS system, equipped with a DB-5MS (30m $\mathrm{x} 0.25 \mathrm{~mm} ; 0.25 \mathrm{~mm}$ film thickness) fused silica capillary column; helium was used as carrier gas, adjusted to a linear velocity of $32 \mathrm{~cm} / \mathrm{s}$ (measured at measured at $100^{\circ} \mathrm{C}$ ); split flow was adjusted to give a 20:1 ratio, and septum sweep was a constant $10 \mathrm{~mL} / \mathrm{min}$. Splitless injection of $1 \mathrm{~mL}$, of a 2:1000 hexane solution; injector and detector temperature was $250^{\circ} \mathrm{C}$; programmed oven temperature was $60^{\circ} \mathrm{C}-240^{\circ} \mathrm{C}$ at $3^{\circ} \mathrm{C} / \mathrm{min}$. the carrier gas was helium. Injection and oven-programming temperature were the same as above. EIMS: electron energy, $70 \mathrm{eV}$; ion source temperature and connection parts: $180^{\circ} \mathrm{C}$. Individual components were identified by comparison of both mass spectrum and their GC retention data with those of authentic compounds previously analyzed and stored in the data system, and by comparison of mass spectra with those in the data system libraries and cited in the literature (Adams,

\footnotetext{
${ }^{1}$ Instituto Nacional de Pesquisas da Amazônia, Coordenação de Pesquisas em Produtos Naturais, CP 478, 69011-970, Manaus, AM, Brasil

${ }^{2}$ Museu Paraense Emílio Goeldi, Coordenação de Botânica, CP 399, 66040-170, Belém, PA, Brasil
} 
1995). Components, retention indices, and percentages are listed in Table 1.

\begin{tabular}{|c|c|c|c|}
\hline Constituents & R I & Leaves & Fine stems \\
\hline$\alpha$-Pinene & 939 & 1.0 & 0.8 \\
\hline Benzaldehyde & 961 & 4.8 & \\
\hline$\beta$-Pinene & 980 & 0.4 & 0.6 \\
\hline Benzonitrile & 985 & 1.2 & 0.4 \\
\hline$\Delta^{3}$-Carene & 1012 & & 0.2 \\
\hline p-Cymene & 1026 & 0.4 & 0.3 \\
\hline Limonene & 1031 & 0.8 & 1.3 \\
\hline 1,8-Cineole & 1033 & 0.2 & \\
\hline Phenylacetaldehyde & 1043 & 0.5 & \\
\hline trans-Linalool oxide & 1089 & & 0.1 \\
\hline Linalool & 1099 & 1.2 & 5.2 \\
\hline Terpinen-4-ol & 1178 & & 0.2 \\
\hline Isomenthol & 1182 & & 0.1 \\
\hline$\alpha$-Terpineol & 1189 & 0.6 & 0.9 \\
\hline Geraniol & 1257 & & 0.2 \\
\hline 1-Nitro-2-phenylethane & 1300 & 71.2 & 68.2 \\
\hline Eugenol & 1357 & 1.0 & 5.2 \\
\hline$\beta$-Elemene & 1375 & 0.2 & 0.2 \\
\hline$\alpha$-Copaene & 1377 & 1.5 & 0.2 \\
\hline (E)-Methyl cinnamate & 1379 & & 0.1 \\
\hline (Z)-Caryophyllene & 1403 & 2.2 & 1.2 \\
\hline Methyl eugenol & 1405 & & 1.1 \\
\hline (E)-Caryophyllene & 1418 & 0.9 & 1.4 \\
\hline$\alpha$-Humulene & 1454 & 0.6 & 0.7 \\
\hline$\beta$-Chamigrene & 1477 & & 0.3 \\
\hline$\beta$-Selinene & 1485 & 4.5 & 1.8 \\
\hline$\alpha$-Selinene & 1494 & 1.1 & 0.9 \\
\hline$\beta$-Bisabolene & 1509 & 0.7 & 0.8 \\
\hline$\delta$-Cadinene & 1525 & 0.3 & 0.5 \\
\hline cis-Calamenene & 1521 & 0.1 & 0.3 \\
\hline Cadina-1,4-diene & 1533 & & 0.1 \\
\hline Elemol & 1550 & & 0.1 \\
\hline (E)-Nerodiol & 1565 & & 0.1 \\
\hline Spathulenol & 1576 & 0.1 & 0.3 \\
\hline Caryophyllene oxide & 1581 & 1.3 & 0.6 \\
\hline Globulol & 1584 & & 0.1 \\
\hline Guaiol & 1595 & 0.1 & 0.4 \\
\hline Humulene epoxide II & 1606 & 0.1 & 0.1 \\
\hline 1-epi-Cubenol & 1629 & & 0.3 \\
\hline Cubenol & 1644 & & 0.2 \\
\hline 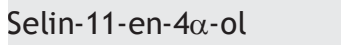 & 1553 & & 3.6 \\
\hline Bulnesol & 1668 & & 0.3 \\
\hline
\end{tabular}

*RI on DB-5MS
As reported in the literature (Gottlieb et al., 1960; Morais et al., 1972) in previous studies of the oil of A. canelilla, 1nitro-2-phenylethane was found to be the major component. According our results the leaf and fine stem oil of the present sample furnished also a high content of 1-nitro-2phenylethane (leaves: $71.2 \%$; fine stems: $68.2 \%$ ). The content of this component in the oil of the stem bark of A. canelilla, that were previously reported presented $89.8 \%$ (Oger et al., 1994 ) and $48.6 \%-94.3 \%$ (Taveira et al., 2003). To the best of our knowledge the chemical composition of the stem oil of A. canelilla is being reported here for the first time.

\section{LITERATURE CITED}

Adams, R. P. 1995. Identification of Essential oil Components by Gas Chromatography/Mass Spectrometry. Allured Publ Corp., Carol Stream, IL, 469 p.

Almeida, E. R. 1993. Plantas medicinais brasileiras. Hemus ed., São Paulo, 341 p.

Corrêa, M. P. 1984. Dicionário das plantas úteis do Brasil e das exóticas cultivadas. Vol II, Imprensa Nacional ed., Rio de Janeiro.

Gottlieb, O. R. \& Magalhães, M. T. 1959. Occurrence of 1-nitro-2phenylethane in Ocotea pretiosa and Aniba canelilla.J. Org. Chem., 24: 2070.

Gottlieb, O. R. \& Magalhães, M. T. 1960. Essential oil of the bark and wood of Aniba canelilla. Perf. Essent. Oil Rec., 51: 69.

Martins, E. C. 1989. Plantas medicinais de uso na Amazônia, 2th ed., Graficentro/Cejup, Belém, 107 p.

Morais, A. A., Rezende, C. M. A. M., Von Büllow, M. V., Mourão, J. C., Gottlieb, O. R., Marx, M. C., Rocha, A. I. da, Magalhães, M. T. 1972. Óleos essenciais do gênero Aniba. Acta Amazonica, 2: 41.

Oger, J. M., Fardeau, A., Richomme, P., Fournet, A., Guinaudeau, H. 1993. Nouveaus alcaloïdes isoquinoléiques isolés d'une Lauraceae bolivienne: Aniba canelilla H. B. K. Can. J. Chem., 71: 1128.

Oger, J. M., Richomme, P., Guinaudeau, H., Bouchara, J. P., Fournet, A. 1994. Aniba canelilla (H. B. K.) Mez Essential Oil: Analysis of Chemical Constituents, Fungistatic Properties.J. Essent. Oil Res., 6: 493.

Taveira, F. S. N., Lima, W. N. de, Andrade, E. H. A., Maia, J. G. S. 2003. Seasonal essential oil variation of Aniba canelilla. Biochem. Syst. Ecol., 31: 69.
RECEBIDO EM 28/05/2003 ACEITO EM 05/03/2004 